\title{
Food and Nutrition Security: Biotechnology Intervention
}

\author{
Lakshminarayana R. Vemireddy
}

Received: 9 February 2014/Revised: 5 May 2014/ Accepted: 6 May 2014/Published online: 22 May 2014

(c) Springer International Publishing AG 2014

\begin{abstract}
Since the dawn of agriculture conventionally used genetic and breeding methods aided substantially to enhance the yield thresholds and defending various pests and diseases. However, many unsolved problems through the conventional methods can be witnessed even after many decades of continuous efforts by the breeders. In this regard, biotechnology is being played an immense role in agriculture by providing better feed and fuel to the growing world. In the present paper, in order to reiterate the significance of this essential technology to those who ridicule it, I reviewed the fruitful outcomes of the intervention of biotechnological tools in food and nutrition security besides offering plausible solutions to inheriting, as well as emerging constraints in a comprehensive and concise manner.
\end{abstract}

Keywords Food security $\cdot$ Biotechnology $\cdot$ Markerassisted breeding $\cdot$ Transgenics

\section{Introduction}

Feeding 9 billion people, anticipated by 2050 with virtually no scope for horizontal growth and shrinking farm resources besides uncertainties in global climate, is an undoubtedly a challenging task. Despite of significant progress in crop breeding especially rice and wheat after the Green Revolution in mid sixties, the plateauing or declining of growth in yield could be witnessed from 1990 onwards. This could be attributed to ceiling of yield threshold,

L. R. Vemireddy $(\bowtie)$

Institute of Biotechnology, Acharya NG Ranga Agricultural

University, Rajendranagar, Hyderabad 500030, India

e-mail: vlnreddi@gmail.com increased pests and diseases, etc. For the past few decades, however, productivity of agricultural crops has been enhanced through the process of advanced plant breeding methods and crop management practices. Recent advances in innovative biotechnological tools aided immensely to the enhanced production, as well as to unravel the issues related to defending biotic and abiotic stresses. The benefits of biotechnology in agriculture are long been supported by the farmers around the world. Breeding of new crop varieties, production of biofertilizers, biopesticides and propagation of material, disease diagnostics and the conservation and management of crop genetic resources are some of the implications of biotechnology. Indeed, biotechnology is not a new science, as it was reported to be, but it exists since 8,000 years when the ancient Sumerians used yeast to make beer. Principles of heredity discovered by Gregor Johann Mendel (July 20, 1822_-January 6, 1884), widely regarded as 'Father of Genetics', provided the foundation for modern biotechnology. According to the Convention on Biological Diversity (CBD), biotechnology defined as 'any technological application that uses biological systems, living organisms, or derives thereof, to make or modify products or processes for specific use' [1]. However, nowadays the term 'biotechnology' is being used only to DNA techniques, molecular biology and genetic engineering methods. In the present context, the CBD definition of biotechnology which covers using of either biological organisms or its products or any other novel biotechnology tools such as molecular biology and genetic engineering methods for human welfare is considered in the current review. Supplementation of biotechnology methods in crop improvement coupled with timely management practices possibly unravels the current and future needs of food security and nutrition. Despite its 20 years of commercialization and success of the many products of biotechnology, still many people ridicule the 
importance of this technology. In this regard, in the present review, implications of biotechnology in agriculture with special emphasis on crop improvement, defending against pests, diseases and weeds besides nutrition security were discussed.

\section{Creation of Genetic Variability}

Important prerequisite in breeding is the availability of variation in the germplasm. It is well-known fact that most of the agricultural crops endowed with rich genetic variability in their germplasm. The source for this variability exists in the form of wild/weedy species, landraces, modern cultivars and induced mutants in addition to the genetic variability created by the transgenic plants and varieties developed using marker-assisted selection (MAS). However, more than $80 \%$ of the present day cultivars have been developed from the few parental lines that are derived from the modern cultivars only. The main reason for heavy dependence on modern cultivars is that most of the breeders are under the impression that the existing variability is adequate to meet the future varietal needs. In addition, strong sexual barriers to introgress the genes from the distant relatives and introduction of undesirable traits (linkage drag) into the adapted cultivars made the breeders reluctant to opt from distant gene pools. However, to cater the needs of the future food requirement, it is inevitable to tap hidden variability of wilds and landraces. Further, over $85-90 \%$ of the still unexploited variability lies unused in landraces and wild/weedy relatives. Thanks to the recent advances in molecular biology techniques which helped to transfer the genes from any distant organism besides. One classic example of the introgression of genomic region from a relative was the use of the short arm of rye chromosome $1 \mathrm{R}$ in wheat. In the early 1990s, this wheat-rye translocation was used in $45 \%$ of 505 bread wheat cultivars in 17 countries [2]. A recent striking example is the improvement of a tomato variety $\mathrm{AB} 2$ with high yield and increased sugar content by introducing a chromosome segments harboring a yield-associated QTL, i.e. Brix9-2-5 from the inedible wild species Solanum pennelii into the genetic background of an elite variety via MAS by a fruitful collaboration of Hebrew University of Jerusalem and the Max-Planck-Institut für Molekulare Pflanzenphysiologie, Golm [3]. Today, the AB2 is the leading tomato variety in California, a largest producer of industrial processing tomatoes in the world.

In crops like rice and wheat no major breakthrough in yields could be achieved after green revolution because of breeder's exclusive dependence on very limited variability for yield-related traits (DGWG in rice and Norin 10B in wheat). To this end, some of the dwarf accessions with alternate gene(s) to widely used Dee-Gee-Woo-Gen allele of $s d-1$ gene in rice have been identified [4]. Recently, in a green super rice (GSR) project, spearheaded by Dr. Zhikang Li, International Rice Research Institute (IRRI) molecular geneticist developed a large collection of rice varieties that retain their stable, sustainable yield potential even when grown with fewer inputs (fertilizer and pesticides) or under unfavorable environmental conditions by crossing 46 recurrent parents with 500 donors [5]. By inclusion of this kind of breeding material, it is possible to broaden the genetic base of the existing germplasm of the rice. However, for certain traits like sheath blight and stem borer resistance in rice there is no source been found in the existing germplasm so far (Table 1). These circumstances prompt breeders all over to create novel and additional variability. Earlier, mutagens (either chemical or radiation) used to be the option to create additional variability in the germplasm. However, the mutants generated were found to be largely lethal in nature. Point mutations, intragenic recombination, transposable elements, activation tagging and soma clonal variations are some of the biotechnology tools being used to generate novel variability. Despite the availability of such large variability in the present day cultivars, it is not clear whether plant breeding methods have reduced or enhanced the genetic diversity since the switch from traditional landraces to modern cultivars. For instance, very recently, Choudhary et al. [6] reported the increase of genetic diversity of major Indian rice cultivars released from 1970 to 2010. A meta-analysis study using 44 published papers related to trends in genetic diversity across crops reveals that there was no narrowing of the genetic base of the varieties released so far over the years [7]. No matter whatever method is used to create variability, there is a need to conserve the existing germplasm. Thanks to the Government of Norway, who took great initiative to construct the 'Svalbard Global Seed Vault' wherein duplicate samples or 'spare' copies of seeds of different genebanks are being stored. The seed vault provides insurance against the loss of seeds in genebanks, as well as a refuge for seeds in the case of large-scale regional or global crises (http://en.wikipedia.org/wiki/Svalbard Global_Seed_Vault).

\section{Propagation of Seed Material}

Many of the long-lived horticulturally important crops where rapid large-scale seed production is a problem, micropropagation and somatic embryogenesis methods of the tissue culture offered considerable solutions. Biotechnology intervention is apparent in recent days in mass multiplication of elite lines or disease-free planting material by culturing in vitro explants such as shoot tips, tuber sections 
Table 1 List of major insect pests and diseases for which no source of genetic resistance exists and their corresponding transgenics developed

\begin{tabular}{llll}
\hline Crop & $\begin{array}{l}\text { Insects/ } \\
\text { diseases }\end{array}$ & Transgenics developed & References \\
\hline
\end{tabular}

\begin{tabular}{|c|c|c|c|}
\hline Insects & & & \\
\hline Rice & Stem borer & crylla5 gene & [74] \\
\hline & & crylAb/crylAc genes & [75] \\
\hline Sorghum & Shootfly & Not available & \\
\hline Pigeonpea & Pod borer & crylAc protein & [76] \\
\hline Chickpea & Pod borer & cry $1 A b$ and cry $1 A c$ & [77] \\
\hline Mustard & Aphids & $\begin{array}{l}\text { Wheat germ agglutinin } \\
\text { (WGA), the chitin- } \\
\text { binding lectin }\end{array}$ & [78] \\
\hline & & Onion Leaf Lectin Gene & [79] \\
\hline & Jassids & Not available & \\
\hline Tomato & Fruit borer & crylAc gene & [80] \\
\hline & & Bt (Cry2Ab) gene & [81] \\
\hline Brinjal & & CrylAa3 gene & [82] \\
\hline Cotton & $\begin{array}{r}\text { Bollworm } \\
\text { complex }\end{array}$ & $\operatorname{Cry} 2 A b$ & [83] \\
\hline Diseases & & & \\
\hline Rice & $\begin{array}{l}\text { Sheath } \\
\text { blight }\end{array}$ & Chitinase gene & [84] \\
\hline & & $\begin{array}{l}\text { Endochitinase (cht42) gene } \\
\text { from Trichoderma virens }\end{array}$ & [85] \\
\hline & & $\begin{array}{l}\text { Thaumatin-like protein } \\
\text { gene (tlp-D34) and } \\
\text { chitinase gene (chil1) }\end{array}$ & [86] \\
\hline Wheat & Karnalbunt & Not available & \\
\hline Chickpea & $\begin{array}{l}\text { Ascochyta } \\
\text { blight }\end{array}$ & Not available & \\
\hline $\begin{array}{l}\text { Green and } \\
\text { Black } \\
\text { gram }\end{array}$ & $\begin{array}{l}\text { Yellow } \\
\text { mosaic } \\
\text { virus }\end{array}$ & Not available & \\
\hline Mustard & $\begin{array}{r}\text { Alternaria } \\
\text { leaf spot }\end{array}$ & Glucanase gene & [87] \\
\hline Groundnut & $\begin{array}{l}\text { Tobacco } \\
\text { streak } \\
\text { virus }\end{array}$ & $\begin{array}{l}\text { Coat protein genes of } \\
\text { Tobacco streak } \\
\text { virus (TSV) }\end{array}$ & [88] \\
\hline Sesame & Phyllody & Not available & \\
\hline $\begin{array}{l}\text { Common } \\
\text { bean }\end{array}$ & $\begin{array}{l}\text { Bean } \\
\text { golden } \\
\text { mosaic } \\
\text { virus }\end{array}$ & $\begin{array}{l}\text { Silence the AC1 viral gene } \\
\text { by RNA interference }\end{array}$ & [31] \\
\hline
\end{tabular}

or other cuttings. Today, using in vitro methods, range of crops including subsistence crops, banana, cassava, yam, potato, sweet potato and cocoyam; commercial plantation crops, such as cocoa, coffee, oil palm, sugar cane and tea; niche crops, such as artichoke, cardamom, garlic, ginger and vanilla; and fruit trees, such as almond, olive, pistachio, pineapple and plantain are being propagated. Biotechnology not only speeds up the large-scale propagation of horticultural crops but also troubleshoots the problems generated by the micropropagation. For instance, 'mantling', a phenotype led to a failure of fruit formation is a major problem in micropropagated material of Malaysian Oil palm. Employing biotechnological methods, the reason for mantling was identified as the altered patterns of DNA methylation that occur during tissue culture [8]. Furthermore, tissue culture techniques are being used for developing seedless fruits or sterile fruits and to create polyploids, especially triploids by embryo culture or regeneration from endosperm. As of now, many seedless fruits have been developed using these methods which include citrus, acacia, kiwi fruit, loquat, passion flower and pawpaw [9].

\section{Enhancement of Productivity}

Despite new plant-type-based varieties and advances in hybrid technology enhanced the yield levels in unprecedented manner after the Green revolution, the burgeoning human population, as well as abnormalities in climate demands intervention of innovative biotechnology tools for crop improvement.

One of the important success stories of biotechnology in productivity improvement comes from the development of NEw RICe for Africa (NERICA) varieties by Africa Rice Centre, Cotonou, Benin formerly known as West Africa Rice Development Association (WARDA) in Africa. NERICA lines were created by crossing Oryza glaberrima, African rice and $O$. sativa, Asian rice by Dr. Monty Jones for which he received world's food prize in 2004. The NERICA lines combine the hardiness and weed suppression of the African rice species with the productivity of the rice species of Asia. Since these two species do not interbred naturally, WARDA breeders sought to biotechnology to overcome the infertility problem by employing embryo rescue [10].

Another significant achievement was the development of striga-resistant sorghum varieties in Africa by Dr. Gabisa Ejeta, world food prize winner-2009. Dr. Ejeta and colleagues employed multi-pronged research approach involving molecular genetics, biochemistry and agronomy to identify gene for striga resistance, and then introgressed into both locally adapted and modern varieties. These sorghum lines were thus broadly been adapted to different African habitats [11].

With the availability of many cloned genes and major QTL related to yield and its components and complete annotation of whole genome sequencing of many crops, now it is possible to develop 'designer crops' by manipulating different agronomic traits such as plant architecture, heading date, seed development, photosynthetic efficiency. For instance, extensive efforts are going on at IRRI to convert the $\mathrm{C} 3$ plant into $\mathrm{C} 4$ plants as photosynthesis 
system of $\mathrm{C} 4$ plants (corn, sugarcane) is more efficient than that of $\mathrm{C} 3$ plants (rice, wheat) by identification of genes responsible for pathway of $\mathrm{C} 4$ mechanism using novel biotechnology tools. Recently, in rice, it was demonstrated that the pyramiding or combining of genes governing plant height and grain number, it was possible to enhance the yields by $25 \%$ [12]. In addition, more insights of the genetic basis of domestication syndrome traits in many crops coupled with detailed genome sequence data and genome synteny offers reasonable room to move key traits between crops or to domesticate new species.

\section{Hybrid Technology}

Hybrid technology is the most successful breeding strategy after new plant-type-based varieties developed during the Green revolution in the history of plant breeding in general and rice in particular. There is growing interest in adopting this technology both to help supply food demand for the increasing world's population and to land conservation as well. For instance, the adoption of the hybrid rice technology enabled China to reduce the total area of land planted from 36.5 Mha in 1975 to 30.5 Mha in 2000, while increasing the yield of 3.5-6.2 tons/ha (http://www.fao. org/rice2004). Thanks to Dr. Yuan Long Ping who greatly regarded as 'Father of Hybrid Rice' for introducing hybrid technology in rice. Understanding the molecular basis of cytoplasmic-genetic male sterility (CMS), as well as other hybrid production methods including self-incompatibility and apomixis, is critical for continued improvements in hybrid technology. The reasons for limited success of this technology in India includes, high cost of hybrid seed, low quality, and insignificant yield edge over the local popular varieties besides lack of awareness too [13]. Inspite of these constraints, this technology is gaining popularity nowadays in India which is evident from the release of approximately 100 rice hybrids which includes first fine grain aromatic hybrid, i.e. Pusa RH-10 from IARI, New Delhi [14].

Detection of Genetic Seed Purity in Parental Lines of Hybrids

Maintenance of genetic seed purity of the parental lines is very important aspect for development of high quality hybrids as even one per cent impurity in the hybrid seed results in in the yield reduction of up to $10 \mathrm{q} / \mathrm{ha}$. Hence, it is essential to make sure of presence of no admixture in the A (male sterile) and B (maintainer) lines in threeway hybrid seed production. Conventionally, the genetic purity is tested through "Grow out test" which usually takes one season apart from wastage of time, space, labor and inputs. To address this problem, molecular markers are being used to distinguish the parental lines at an early stage of hybrid development [15]. Further, marker-assisted breeding has been used for the improvement of parental lines resistant to bacterial leaf blight (BLB) and blast [16]. Very recently, molecular marker system has been developed for identification of restorer lines using tightly linked markers of the $R f 3$ and $R f 4$ fertility restorer loci of WA-CMC in rice [17].

\section{Male Sterility-Restorer System}

Male sterility can be defined as inability of a plant to produce fertile pollen. For successful hybrid seed production, not only genetic purity of parental lines is essential but also the availability of CMS and restorer system. CMS line is identified spontaneously in a population or may arise from intra specific, inter specific, or inter generic crosses. Biotechnological tools such as micropropagation, embryo rescue, protoplast fusion and somatic embryogenesis aid in either maintenance and or creation of male sterile lines. As of now, numerous asymmetric somatic hybrids or cybrids have been produced as a means to transfer CMS into crop plants such as rice, rapeseed, potato, tobacco. Given the availability of tightly linked molecular markers for male sterility and restorer genes, now it is easy to convert any other variety into male sterile lines. For instance, Hui et al. [18] developed a male sterile line using molecular MAS in Chinese cabbage. In crops where there is no natural CMS-fertility restorer system, genetically engineering barnase-barstar system can be successfully used for the development of hybrids. This system was developed by Dr. C. Mariani and his group from Belgium from a bacterium Bacillus amyloliquifaciens and used for the development of transgenic in Brassica napus. This technology can be extended to other non-traditional crops as well [19].

\section{Defending Stresses}

\section{Biotic Stress}

Biotic stresses are one of the key yield depressing factors in crop improvement. Despite availability of many pesticides to control range of insects and diseases, owing to their health hazardous nature and unaffordable prices, development of biotic stress-resistant varieties employing advanced molecular breeding and biotechnological tools gaining popularity. In situations, wherein, unavailability of resistance gene sources in existing natural germplasm and effective screening/selection techniques, biotechnological intervention is warranted. 
Protection Against Insect Pests

Many insecticidal proteins and molecules are available in nature to control insect pests. Tools of molecular biology and genetic engineering can help in harnessing and deployment of these molecules in target crops. Especially it is apt to recall the pioneering work of 2013 World Food Prize Laureates Marc Van Montagu, Mary-Dell Chilton and Robert Fraley whose remarkable contribution in plant cell transformation using recombinant DNA by Agrobacterium gene transfer approach set the stage for genetic engineering crop plants. Major genes encoding insecticidal molecules widely used for developing transgenic plants are endotoxin crystal (cry) proteins of Bacillus thuringiensis, digestive enzyme-specific proteinase inhibitors, plant lectins, $\alpha$-amylase inhibitors, insect chitinases, plant metabolic enzymes and insecticidal viruses [20]. Following the revolutionary effort of developing $B t$ cotton, many institutions including public and private sector organizations have come out with $B t$ transgenics in rice, tomato, brinjal, etc., using diverse $B t$ genes accessed from various sources. The highest number of transgenic events for insecticidal resistance can be observed in crops such as maize, cotton and potato. Apprehensions about GM crops in public and availability of some of the resistance sources in crops, made the researchers to look for genes/QTLs for resistance to different pests so that they can easily be introgressed into the elite cultivars by MAS strategy. Surprisingly, as of now, none of the varieties have been developed for insect pest resistance in any crops using MAS (Table 2). However, employing MAS, three Bt genes, i.e. cry1Ac, cry1C and cry $2 \mathrm{~A}$, were introgressed to 9311 and Fuhui 838, elite parental rice lines being used for hybrid seed production in China, from the donor parents, Minghui63 (cry1C), Minghui63 (cry2A), Minghui63 (cry1Ac). These improved lines showed strong resistance to the pests without much penalty in agronomic traits [21].

\section{Bioprotection or Biological Control}

Although synthetic pesticides dominated the agriculture in controlling the pests for many decades, now people are turning back to biological control methods owing to their target specificity and environmental safety [22]. Biological control can be defined as 'the use of living organisms to suppress the population density or impact of a specific organism, making it less abundant or less damaging that it would otherwise be'[23]. A broad spectrum of biological control agents have been identified worldwide and are being investigated for deployment in controlling different insects by predators. Among biological agents, microbial pesticides are very widely used agents for controlling pests. One among them is crystalline (cry) proteins produced by the Bacillus thuringiensis bacterium. Other biological agents are pheromones, growth regulators and hormones. These agents are very beneficial as they substitute chemical pesticides which are unaffordable, as well as environmentally unhealthy for use in resource-poor faming systems. Fungi are also a known potential agent to replace chemical pesticides. One worth mentioning example is the controlling of desert locust, a sporadic pest in wide areas of North Africa by a combination of Metarhizium fungi plus phenylacetonitrile, a hormone that effect swarming behavior of locusts. Also, Metarhizium strains have been used as an effective control agent against rhinoceros beetle [24].

Biocontrol agents include not only whole organism but also their metabolites and macromolecules which are being employed to control insect pests. Among others, entomopathogenic fungi are successfully used to control insects. The fungal spores or conidia of them when come in contact with the insect cuticle, they germinate, penetrate and proliferate in the insect tissue by sucking up all its nutrients. The spores or conidia have been formulated for use as insect control agents and sold under different trade names such as Bio-power, Bio-Catch and Bio-Magic. Important entomopathogenic fungi are Metarhizium anisopliae, Beauvaria bassiana, Nomuraea rileyi, Trichoderma viride, Lecanicillium muscarium, etc. Entomopathogenic viruses also can as well be used for control of insect pests. For instance, Nucleopolyhedrosis virus (NPV) infects Helicoverpa armigera, Spodoptera litura and Hyblaea puera, whereas Granulo viruses control Chilo infuscatellus and Plutella xylostella. Parasitoids like Trichogramma chilonis and entomopathogenic nematodes such as Steinernema carpocapsae, S. bicornutum and Heterorhabditis indica are also powerful insecticidal biocontrol agents. In India, International Centre for Genetic Engineering and Biotechnology (ICGEB), New Delhi has successfully evaluated and registered a liquid formulation of Photorhabdus luminescens, a gammaproteo bacterium which is harbored in the gut of the entomopathogenic nematode $H$. indica and produces insecticidal toxin complex A (Tc A). This formulation has been commercialized under a trade name 'Bioprahar'. In addition, RNAi mediated approaches also being explored to control the insect pests. Transgenic plants expressing double-stranded RNA of a cytochrome p450 gene control the cotton bollworm larvae effectively by retarding its growth. Likewise, plant extracts from Azadirachta indica (Neem oil) containing azadirachtin and their limonoids have been successfully used against whiteflies, thrips and aphids, with trade names of Nimbecidine EC and Margosom EC [25]. 
Table 2 Commercially available MAS-varieties developed by the public institutions

\begin{tabular}{|c|c|c|c|c|c|c|c|}
\hline Plant & $\begin{array}{l}\text { Cultivar/ } \\
\text { breeding line }\end{array}$ & Trait & & Country & $\begin{array}{l}\text { Year of } \\
\text { release }\end{array}$ & Breeder & References \\
\hline \multirow[t]{4}{*}{ Barley } & Tango & Disease resistance & & USA & 2000 & $\begin{array}{l}\text { Oregon State } \\
\text { University }\end{array}$ & [89] \\
\hline & SloopSA & Disease resistance & & Australia & 2002 & $\begin{array}{l}\text { University of } \\
\text { Adelaide }\end{array}$ & {$[90]$} \\
\hline & GairdnerPlus & Disease resistance & & Australia & 2006 & $\begin{array}{l}\text { University of } \\
\text { Adelaide }\end{array}$ & {$[90]$} \\
\hline & Doria & Disease resistance & & Italy & 2006 & $\begin{array}{l}\text { Istituto Sperimentale } \\
\text { per la Cerealicoltura }\end{array}$ & [91] \\
\hline \multirow[t]{4}{*}{ Bean } & USPT-ANT-1 & Disease resistance & & USA & 2004 & USDA-ARS & [92] \\
\hline & ABCP-8 & Disease resistance & & USA & 2005 & $\begin{array}{l}\text { University of } \\
\text { Nebraska/USDA- } \\
\text { ARS }\end{array}$ & [93] \\
\hline & ABC-Weihing & Disease resistance & & USA & 2006 & $\begin{array}{l}\text { University of } \\
\text { Nebraska/USDA- } \\
\text { ARS }\end{array}$ & [94] \\
\hline & USDK-CBB-15 & Disease resistance & & USA & 2006 & USDA-ARS & [95] \\
\hline Maize & Vivek QPM 9 & $\begin{array}{l}\text { High-lysine and } \\
\text { tryptophan }\end{array}$ & Opaque-2 & India & 2008 & $\begin{array}{l}\text { Indian Council of } \\
\text { Agricultural } \\
\text { Research }\end{array}$ & [96] \\
\hline $\begin{array}{l}\text { Pearl } \\
\text { millet }\end{array}$ & HHB 67-2 & $\begin{array}{l}\text { Resistance to } \\
\text { downey mildew }\end{array}$ & Unknown gene & India & 2005 & $\begin{array}{l}\text { Haryana Agricultural } \\
\text { University/ } \\
\text { ICRISAT }\end{array}$ & [97] \\
\hline \multirow[t]{12}{*}{ Rice } & Cadet & Lowamylose & & USA & 2000 & $\begin{array}{l}\text { Texas Agricultural } \\
\text { Experiment Station }\end{array}$ & [98] \\
\hline & Jacinto & Lowamylose & & USA & 2000 & $\begin{array}{l}\text { Texas Agricultural } \\
\text { Experiment Station }\end{array}$ & [98] \\
\hline & XieYou 218 & Disease resistance & & China & 2001 & $\begin{array}{l}\text { China National Rice } \\
\text { Research Institute }\end{array}$ & [99] \\
\hline & Angke & Disease resistance & & Indonesia & 2002 & n.k. & [100] \\
\hline & Conde & Disease resistance & & Indonesia & 2002 & n.k. & {$[100]$} \\
\hline & Tubigan 7 & Disease resistance & & Philippines & 2006 & $\begin{array}{l}\text { Philippine Rice } \\
\text { Research Institute }\end{array}$ & [101] \\
\hline & Tubigan 11 & Disease resistance & & Philippines & 2007 & $\begin{array}{l}\text { Philippine Rice } \\
\text { Research Institute }\end{array}$ & [102] \\
\hline & MAS 946-1 & Drought tolerance & & India & 2007 & $\begin{array}{l}\text { University of } \\
\text { Agricultural } \\
\text { Sciences }\end{array}$ & [103] \\
\hline & Pusa1460 & $\begin{array}{l}\text { Resistance to } \\
\text { bacterial blight }\end{array}$ & xa13, Xa21 & India & 2007 & $\begin{array}{l}\text { Indian Agricultural } \\
\text { Research Institute }\end{array}$ & [104] \\
\hline & RP Bio 226 & $\begin{array}{l}\text { Resistance to } \\
\text { bacterial blight }\end{array}$ & xa5, xa13, Хa21 & India & 2007 & $\begin{array}{l}\text { Directorate of Rice } \\
\text { Research }\end{array}$ & [105] \\
\hline & Swarna Sub1A & $\begin{array}{l}\text { Submergence } \\
\text { tolerance }\end{array}$ & Sub1A & Philippines & 2007 & $\begin{array}{l}\text { International Rice } \\
\text { Research Institute }\end{array}$ & {$[106,107]$} \\
\hline & $\begin{array}{l}\text { Birsa Vikas } \\
\text { Dhan111 } \\
\text { (PY84) }\end{array}$ & $\begin{array}{l}\text { Early maturity, } \\
\text { drought tolerance } \\
\text { and high yield }\end{array}$ & $\begin{array}{l}\text { Multiple QTLs related to } \\
\text { root growth }\end{array}$ & & & & \\
\hline Soybean & JTN-5303 & Disease resistance & & USA & 2005 & $\begin{array}{l}\text { University of } \\
\text { Tennessee and } \\
\text { USDA-ARS }\end{array}$ & [108] \\
\hline Tomato & Ab2 & High yield & & USA & 2002 & $\begin{array}{l}\text { Hebrew University of } \\
\text { Jerusalem }\end{array}$ & [109] \\
\hline Wheat & Patwin & $\begin{array}{l}\text { Resistance to stripe } \\
\text { and leaf rust }\end{array}$ & Yr17, Lr37 & USA & 2006 & $\begin{array}{l}\text { University of } \\
\text { California, Davis }\end{array}$ & [110] \\
\hline
\end{tabular}


Table 2 continued

\begin{tabular}{|c|c|c|c|c|c|c|c|}
\hline Plant & $\begin{array}{l}\text { Cultivar/ } \\
\text { breeding line }\end{array}$ & Trait & & Country & $\begin{array}{l}\text { Year of } \\
\text { release }\end{array}$ & Breeder & References \\
\hline & Expresso & Disease resistance & & USA & 2006 & $\begin{array}{l}\text { University of } \\
\text { California, Davis }\end{array}$ & [111] \\
\hline & Lassik & $\begin{array}{l}\text { Resistance to stripe/ } \\
\text { leaf rust and } \\
\text { stronger gluten and } \\
\text { high protein } \\
\text { content }\end{array}$ & $\begin{array}{l}\text { GluA11, GluD1 } 5+10 \\
\text { GpcB1, Yr36, Lr37/ } \\
\text { Yr17/Sr38 }\end{array}$ & USA & 2007 & $\begin{array}{l}\text { University of } \\
\text { California, Davis }\end{array}$ & [111] \\
\hline & Farnum & $\begin{array}{l}\text { Disease resistance } \\
\text { and Protein } \\
\text { content }\end{array}$ & Yr36, Gpc-B1 & USA & 2008 & $\begin{array}{l}\text { Washington State } \\
\text { University }\end{array}$ & [112] \\
\hline & Westmore $^{\mathrm{a}}$ & $\begin{array}{l}\text { Disease resistance } \\
\text { and Protein } \\
\text { content }\end{array}$ & & USA & 2007 & $\begin{array}{l}\text { University of } \\
\text { California, Davis }\end{array}$ & [113] \\
\hline & AGS2026 & Disease resistance & & USA & 2007 & University of Georgia & [111] \\
\hline
\end{tabular}

ICRISAT International Crops Research Institute for the Semi-Arid tropics, $n . k$. not known, USDA-ARS United States Department of AgricultureAgricultural Research Service

${ }^{\mathrm{a}}$ Westmore is a durum wheat variety

\section{Protection Against Pathogens}

Molecular strategies employed against diseases vary with the pathogen. In the case of fungal and bacterial diseases, especially if they are multi racial and race-specific resistance is available as in the case of rusts in wheat (Puccinia triticina causes 'black rust', $P$. recondita causes 'brown rust' and $P$. striiformis causes 'Yellow rust') and blast (Magnaporthe grisea) and BLB (Xanthomonas oryzae) in rice. Gene pyramiding in different harmonious combinations of resistance genes using race-specific markers provides wide spectrum, durable and enhanced level of resistance [26]. For BLB in rice, combination of Xa21 alone or with some of the critical resistance genes like $\mathrm{Xa4}$, $x a 5, x a 13, X a 14$, etc., gives high level of protection against the disease. Similarly in the case of rice blast also staking together of region-specific harmonious resistance genes has been reported to provide very high and durable resistance to the pathogen. Indian scientists made significant progress in the development of varieties resistant to different diseases employing MAS. As of now three resistant varieties viz., HHB 67-2 for powdery mildew, RPBIO226 and Pusa1460 for BLB have been released in Pearl millet and rice, respectively (Table 2). In cases of disease causing agents, which do not have resistance sources in the gene pool, various genetic engineering strategies have been adopted based on increasing understanding of molecular events occurring during plant-pathogen interactions. As for the fungal pathogens, the strategies tried out include manipulation of expression of antifungal compounds, which broadly include pathogenesis-related proteins (PR), ribosome inactivating proteins (RI) and metabolites like phytoalexins, resistance genes ( $R$ genes) from plants [27].

\section{Viral Diseases}

Among plant diseases, viral diseases which are seldom managed by host plant resistance cause heavy crop losses. While there are many effective chemical treatments and agronomic practices are available to control fungi, bacteria and nematode, there are no equivalent virus control agents. Virus control, therefore, rests on endogenous resistance of the plant itself. If a plant is susceptible to virus, it can devastate entire crop. This has prompted efforts to deploy genetic engineering approaches for the development of virus resistance crop plants.

There are two approaches for engineering resistance in terms of source of the gene, i.e. they can be either from the virus itself or from other sources. The former is based on pathogen-derived resistance (PDR), wherein transferring of a part or the complete gene provides desired resistance by interfering with one or more steps in the life cycle of the virus. Use of PDR to control viral disease was reported in the form of coat protein-mediated resistance (CPMR) [28]. Since then, there have been growing number of examples of development of viral-resistant crops can be witnessed. The first commercial sale of virus-resistant squash was developed by Asgrow Co in 1995 by transferring coat proteins of zucchini yellow mosaic virus (ZYMV) and watermelon mosaic virus (WMV) (Kalamazoo, MI, USA) [29]. Later, another notable product using this method resulted in resistant papaya varieties to papaya ringspot 
virus (PRSV) in Hawaii in 1998 [30]. The other approach being gained popularity is RNA-mediated virus resistance. Using this approach, bean golden mosaic virus (BGMV)resistant common beans line (named Embrapa 5.1) was developed in Brazil [31, 32].

Wild species are known for their resistance to multiple diseases and pests. Rice grassy stunt virus is a serious disease in Asia to which hardly any natural resistance is available. This virus is transmitted to the plant by a brown planthopper, Nilaparvata lugens. IRRI (Manila, Philippines) scientists released three virus resistance varieties in 1974 using Asian progenitor accession Oryza nivara with the help of tissue culture methods as it is difficult to develop hybrids between wild and cultivated varieties using conventional breeding methods [33]. It is wellknown fact that new crop pests and diseases are constantly evolving with increased global transportation and trade across the world. In these circumstances also biotech methods have a significant role in surveillance and detection and combating such threats in breeding programmes. Rapid identification of new pathogens and especially their genome sequences will facilitate the development of control strategies based on earlier experiences with the pathogen. Though, as of now, no variety has been released for any virus resistance in plants applying MAS, efforts are underway to identify the major QTLs governing it. For instance, CIMMYT is attempting to incorporate major QTL for maize streak virus, prevalent in African countries into elite maize varieties through MAS.

\section{Disease Diagnosis}

Finding the causal agent for a disease is important due to many viral diseases exhibit similar symptoms. Knowledge of the nature of the pathogen is necessary to develop and apply appropriate management measures. Biotechnology offers to diagnose the diseases of both viral and bacterial origin. Popularly used techniques for disease diagnostics are enzyme-linked immunosorbent assay (ELISA) [34], monoclonal antibodies [35] and DNA-based methods [36]. These diagnostic techniques are routinely used for quarantine systems, production of seeds and other propagation material.

\section{Weed Management}

Weed control is one of the most important issues to be addressed in the crop improvement. Since the Green revolution, agricultural crops depended heavily on chemical agents, i.e. herbicides and pesticides to ensure higher yields which led to the turning of breeders attention from the improvement of traits related to weed competition to higher yield. Subsequent increased use of herbicides and pesticides caused detrimental effect on the environment, as well as on human health. While biological control contemplated as an enviable alternate option for these biotic stresses they often proved ineffective in practice. Employment of crop management practices and application of pre-emergence herbicides could not control weeds effectively. Recent advancements in biotechnology effectively being tackled this problem.

\section{Herbicide Tolerant Crops}

Development of herbicide tolerant plants through biotechnological means especially genetic engineering methods would confer solution to the yield loss caused by the weeds without impairment of the crop. Among commercially registered transgenic plants, the highest number constitutes herbicide tolerance only (Fig. 1). This herbicide tolerance crops have been increasingly used worldwide covering an area of 100 of 170 Mha of GM crops (http://www.isaaa. org/resources/publications/pocketk/foldable/Pocket $\% 20 \mathrm{~K}$ $16 \% 20$ (English).pdf. However, the risk of horizontal gene flow, from transgenic crops to weeds by which the latter one gain novel characteristics, demand the use of alternative methods with least impact on the environment [37].

\section{Allelopathic Effect}

Allelopathy, an effect of one plant on another mediated through the exudation of chemical compounds that escape into the environment, is regarded as one of the promising methods of controlling weeds effectively. The allelopathic effects might include direct influence of root exudates excreted in the rhizosphere and/or release of allelopathic compounds during decomposition of plant residues. Accumulated evidence shows that there are large differences between crop cultivars in their allelopathic effect. This variability led to the identification of many genomic regions or quantitative trait loci (QTLs) associated with allelopathy in various crops such as rice, wheat, maize, oats and rye [38]. Identification of QTLs for allelopathy-related traits suggest a possibility of transferring these QTL regions into elite cultivars via MAS. However, the effectiveness of allelopathy on weed control largely relies on combining of crop management practices with ecological, physiological, biochemical and molecular processes. For example, using of cultivars with enhanced allelopathic activity in crop rotation could effectively control the weeds [39].

\section{Weed Genomics}

The genomic approaches extended to gain better insights in the area of weed biology, called as 'weed genomics'. This new science has implications in agriculture. Firstly, it helps 

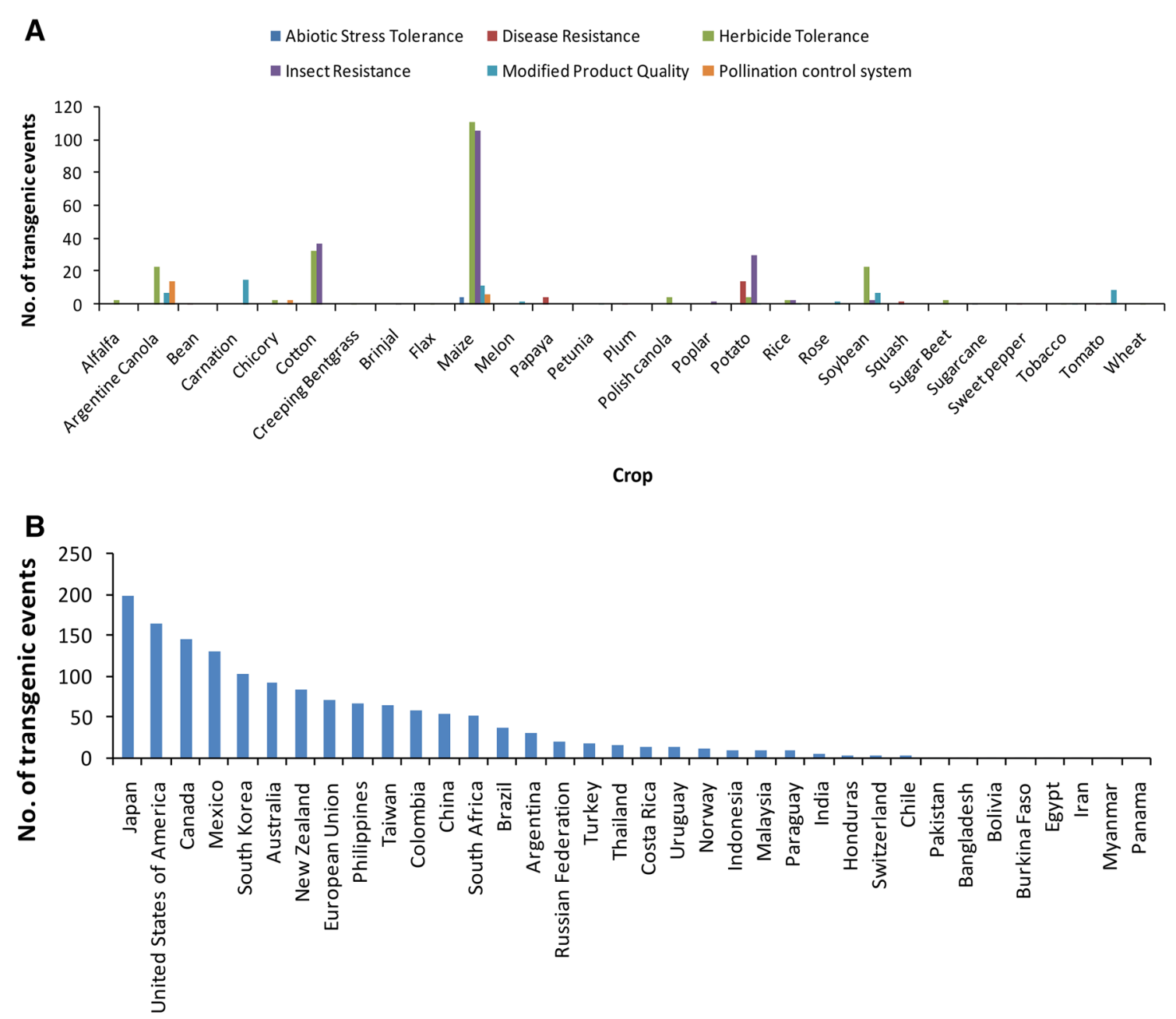

Country

Fig. 1 Status of approved GM crops. a Cropwise and traitwise approved GM crop events. b Countries with GM crop approval

in the identification of novel genes of economic value from weeds. For instance, several weeds are tolerant to aluminum, a trait that is virtually absent from field crops. Secondly, improve the understanding of herbicide resistance and subsequently identification of novel herbicide targets. Thirdly, our understanding of weed biology would be enhanced greatly [40].

\section{Abiotic Stresses}

Among abiotic stresses that severely repress productivity of crop plants, drought, submergence and temperature extremes are important. One of the ecosystems, wherein tremendous scope exists to narrow the yield potential and current yield of crops is rainfed ecosystem which covers 170 Mha of land in the world. Plant's ability to withstand such stresses results from cumulative effect of component physiological and biochemical functions. The breeding of drought-tolerant varieties by conventional approaches is hampered mainly by the complex, polygenic nature of drought tolerance, and their complicated screening techniques. However, there have been some successes in developing drought tolerance by conventional breeding. One of the noteworthy examples is the open-pollinated maize variety ZM521 developed by the International Maize and Wheat Improvement Centre (CIMMYT), Mexico. The variety ZM521 not only exhibits remarkable vigour when afflicted by water shortage, but also yields between 30 and $50 \%$ more than traditional varieties under drought [41]. The wheat varieties Drysdale and Rees are two further notable examples showing that conventional breeding can develop drought tolerance using the DELTA technique, a gene selection approach based on carbon isotope discrimination by Australia's Commonwealth Scientific and Industrial Research Organization (CSIRO). Drysdale 
reported to outperform other varieties by up to $40 \%$ under very dry conditions [42].

The MAS strategy also has greatly helped in the development of drought tolerance varieties. A first drought tolerant aerobic rice variety, i.e. MAS 946-1 released in India in 2007 from the University of Agricultural Sciences (UAS), Bangalure by crossing a deep-rooted upland japonica variety from the Philippines, i.e. Azucena with a high yielding indica variety Kalinga III by MAS strategy. The newly bred variety consumes up to $60 \%$ less water than traditional varieties [43]. Another promising product of MAS is the development of submergence tolerant variety Swarna $s u b l$ in rice. Normal rice varieties are intolerant to complete flooding more than 3 days, whereas varieties with the $s u b 1$ gene from FR13A can survive up to 2 weeks or more. This gene was also incorporated into other mega rice varieties, i.e. BR11-Sub1, IR64-Sub1 by IRRI using MAS [44]. The Water Efficient Maize for Africa (WEMA) program developed drought tolerant maize employing MAS by the African Agricultural Technology Foundation, CIMMYT and Monsanto, is going to be released commercially in the US in 2014 and in Sub-Saharan Africa by 2017 [45].

Knowledge Transfer from Model Plants to Crop Plants for Better Understanding of Abiotic Stress Tolerance

The Arabidopsis, a well-known model plant in molecular biology has allowed the identification of many genes involved in pathways of different stress tolerant mechanisms. Most promising breakthroughs of basic biology in the last decade include understanding of abscisic acid (ABA) biosynthesis, ABA receptors and ABA signal transduction pathway. The detailed understanding of it undoubtedly broadens our understanding of drought tolerance. Biotechnological approaches to improve stress tolerance in plant broadly may involve over expression or suppression of genes involved in particular aspects of cellular homeostasis such as somatic adjustments, chaperons or antioxidants. Besides, genes encoding members of the AP2/ERF transcription factor family including the dehydration response element binding protein (DREB), ABA response element binding proteins (AREB) and NAC transcription factors have all shown promise in addition to genes encoding signal transduction such as kinases and protein modification enzymes [46]. Attempts are being made to develop salinity tolerant transgenic varieties using identification of unique genes from Mangrove plants by MS Swaminathan Research Foundation (MSSRF) [47], Chennai. Likewise, ICGEB, New Delhi, also being attempted to develop transgenic salinity tolerant rice by engineering glyoxalases [48] and helicases [49] apart from basic understanding of the salinity tolerance, a complex trait. MicroRNA, a small non-coding RNA molecules also demonstrated to have great role in control of drought tolerant mechanisms [50].

\section{Microbial Symbiosis for Abiotic Stress Tolerance}

Naturally occurring soil microbes may be used as inoculants to maintain crop yields despite decreased inputs especially water and nutrients. Microbial symbiosis often alters rates of water movement into, through and out of host plants, thereby altering tissue hydration. Under drought, arbuscular mycorrhizal (AM) fungi-infected plants show higher stomatal conductance and transpiration rates than non-AM plants which have been correlated with altered phytohormone ratios. In addition, AM symbiosis can compensate limited water availability during intermittent periods of drought or when irrigation volumes are reduced by maintaining plant water status, thereby improving crop water use efficiency [51]. Recent studies have shown that many of the plant growth-promoting rhizobacteria (PGPR) enhance tolerance to abiotic stresses especially drought and salinity [52].

\section{Plant Nutrition}

As with biopesticides or biological control agents, biofertilizers, nitrogen-fixing bacteria and/or mycorrhizal fungi also have implications to enhance the yield levels in plants. Biofertilizers not only reduce the input cost to the farmers but also environmentally safe as they prevent accumulation of nitrates and phosphate within soils. There are many instances where the biofertilizers can be used as an alternative to chemical fertilizers. For example, rhizobial inoculants were used to augment the nutritional status of soybean, groundnut and mungbean crops in Thailand [53]. A marketable biofertilizer based on Rhizobium inoculants, i.e. Biofix was developed for sorghum by Kenya in a 'Microbial Resistance Centre Network' (MIRCEN) project of UNESCO. This is the first success story of biofertilizers that has been in use since 1981 [54]. Subsequently, a Rhizobium-based biofertilizer developed by the National University of Mexico for common bean was commercialized in 2003 under the trade name of 'Rhizofer' [55]. It is being sold either on its own or in combination with spores of the mycorrhizal fungus Glomus intraradices. Similarly in Philippines, inoculums of rice straw mixed with the fungus Trichoderma have reduced the composting time to as little as 21-45 days depending on the type of plant residue used. This process popularly called as 'rapid composting technology' (RCT) [56]. 
Integrating rhizobacteria within nutritional management programmes undoubtedly reduce but not eliminate chemical fertilizer applications, by exploiting bacterial nitrogen fixation and/or phosphate solubilization. For instance, soil inoculum with two PGPR strains (Bacillus amyloliquefaciens IN9379 and Bacillus pumilus T4) in isolation form, or in combination with the AMF $G$. intraradices, sustained tomato fruit yield despite application of less fertilizer, by increasing nitrogen uptake of applied fertilizer, but not from residual nitrogen [57]. Microbial inoculants, however, could not sustain the yield once fertilizer rates dropped below $70 \%$ of the recommended rates. Plants inoculated with AMF can decrease recommended phosphate fertilizer requirements by up to $80 \%$ depending on the growing conditions and also significantly decrease nitrogen requirements, thereby improving crop nutrient use efficiency [58].

\section{Nutrition and Quality Enhancement}

Most of the staple crops are nutritionally deficient in some respect either in vitamins or micronutrients or amino acids which led to different forms of malnutrition especially for children and pregnant woman. Enrichment of micronutrients (iron and zinc), amino acids (lysine and tryptophan) and vitamins in the food supplements-regarded as 'Biofortification' - is of immense value to combat malnutrition in the world. Using conventional breeding, provitamin A enhanced orange-fleshed sweet potato varieties have been developed through 'Vitamin A for Africa' (VITAA) program comprising mainly International Potato Centre (CIP), Chile together with other organizations (www.cipotato.org/ vitaa/pubs2008/VITAA.pdf). Likewise, CIMMYT succeeded in developing quality protein maize (QPM) having enhanced levels of lysine and tryptophan. However, laborious and time-consuming nature of conventional breeding and availability of molecular markers prompted plant breeders all over to opt for MAS. To this end, India succeeded in developing first QPM hybrid, i.e. Vivek QPM9 employing MAS (Table 2). Similar kind of program has been initiated in other Asian countries like Vietnam, China and Indonesia. In order to combat the malnutrition, HarvestPlus consortium initiated to focus three dietary micronutrients recognized by the World Health Organization (WHO) viz., iron, zinc and vitamin A in six staple food crops, i.e. rice, wheat, maize, cassava, sweet potato and common bean employing all available biotechnologies including MAS and genomic tools [59].

When there is no genetic variability for traits like beta carotene in the existing germplasm of all cereals except maize, the only option that receives much attention is genetic engineering (GE). The first successful example of nutritional enrichment by GE method stems from the development of beta carotene rich 'Golden rice' by incorporating two genes, i.e. phytoene synthase (psy) from Dffodil (Narcissus pseudonarcissus) and Crtl from a bacterium Erwinia uredovora which convert the lycopene to beta carotene in provitamin A biosynthesis pathway [60]. However, the first generation 'Golden rice' accumulates very less concentration of beta carotene $(1.6 \mu \mathrm{g} / \mathrm{g})$ due to the presence of daffodil gene (psy) that found to be limiting step in beta carotene accumulation. Later, using psy gene from maize, 'Golden rice 2' has been developed which exhibits the beta carotene concentration up to 23 -folds. i.e. $37 \mu \mathrm{g} / \mathrm{g}$ compared to the original golden rice [61]. Though golden rice has been developed in 1999 still it is struggling to clear regulatory hurdles. The Rockefeller Foundation is providing funds to help guide golden rice through national regulatory approval processes in Bangladesh, India, Indonesia and the Philippines. The golden rice traits or related genes are being transferred into local popular varieties using MAS approach. In 2005-2007, IRRI transferred this trait to IR64. Recently, through association analysis, linkage mapping, expression profiling and mutagenesis, it has been demonstrated that variation at lycopene epsilon cyclase ( $\mathrm{LycE}$ ) gene favorably alters the flux down alpha versus beta carotene branches of the carotenoid pathway in maize [62]. Most recently, a functional variant of another gene, hydroxylase-b1 (Hydb-1/ CrtRB1) that governs conversion of beta carotene into beta cryptoxanthin has been discovered in maize [63]. Now CIMMYT is being attempted to develop robust, easy to use functional markers for LycE and CrtRB1/(Hydb-1) genes for enhanced provitamin A content in maize through MAS [64]. In India, National Institute of Plant Genome Research (NIPGR), New Delhi came up with nutritionally rich transgenic potato developed using quality protein gene, i.e. AmAl from leafy vegetable Amaranthus [65]. Now this gene has been transferred to rice to enhance the protein content. Another, notable achievement of this institute is identification of genes governing tomato shelf life, i.e. $\alpha$-mannosidase and $\beta$-D- $N$-acetylehexosaminidase [66]. Also, an iron-rich transgenic variety transferred with ferritin gene developed in rice [67].

\section{Edible Vaccines}

Edible vaccines are known to as better replacement for traditional vaccines where storage and administration is a problematic to combat the infectious diseases such as diarrhoea and hepatitis especially in developing countries. Edible vaccines are manufactured by the genetic engineering methods by transferring the selected genes into widely grown crop plants such as rice, wheat, maize, banana, potato, tomato, soybean and lettuce. Accumulated reports provided the proof of principle that manufacturing edible vaccines is 
feasible. The first edible vaccine expressed the Streptococcus mutans surface protein antigen $\mathrm{A}(\mathrm{SpaA})$ in tobacco at $0.02 \%$ leaf protein level was reported in 1990 [68]. Arakava et al. [69] developed transgenic potato plants that synthesize human insulin. Subsequently, expression of the hepatitis B surface antigen (HbsAg) [70], the E. coli heat-labile enterotoxin responsible for diarrhoea, the Norwalk virus capsid protein and the rabies virus glycol protein in tomato [71] have been reported.

\section{Prevention of Post Harvest Losses}

Senescence retardation in horticultural crops (fruits and vegetables) is major thrust area to prevent post harvest losses. It gains further importance under tropical and subtropical conditions where senescence is much more rapid and an energy cost of cold storage is very high. The control over senescence was achieved by introduction of gene for ACC Synthase in tomato [72].

\section{Trade and Authenticity}

Genuineness or authenticity of agricultural products being exported is one of the key aspects in trade to protect the interests of importers, as well as exporters. In the market, different grades of agri products with varying prices exist. Of them, certain premium products like Basmati rice receives zero per cent import duty by the importing countries. This circumstance indeed lures dishonest traders and millers to go for adulteration with cheap quality products of low price. Traditionally used morpho-physical methods failed to unravel this menace effectively on commercial scale. Again, here also, DNA-based molecular markers have shown great role to resolve this problem. A microsatellite marker-based highthroughput multiplex protocol has been developed by Centre for DNA Fingerprinting and Diagnostics (CDFD) to detect and quantify the adulteration accurately in export samples of Basmati rice. This protocol is based on capillary electrophoresis and uses eight microsatellite markers viz., RM1, RM72, RM 171, RM241, RM202, RM55, RM44 and RM348 which can detect the adulteration even at $1 \%$ level. 'APEDA-CDFD centre for Basmati DNA analysis' housed at CDFD, Hyderabad is the only authorized centre in India to confer authenticity certificate to export samples of Basmati rice [73].

\section{Conclusions and Future Perspectives}

Biotechnology has the potential role in food and nutrition security. However, it cannot be considered as panacea for all the problems in the agriculture and also too early to judge its impact on sustainable development. Despite promising products delivered so far, alternate approaches also should be considered in integrated manner. Completion of whole genome sequencing of crop plants culminated umpteen number and various types of molecular markers which have the potential to expedite the plant breeding process besides unraveling the genetic purity and adulteration problems. The knowledge gained from the basic research on model plants could be extended to better understand the complex biological mechanisms/pathways of crop plants. Although, the end user decides whether to opt a transgenic or non-transgenic product in the market, as a new generation tool, the biotechnology tools are deserve to be welcomed in addressing food and nutrition security problems.

Conflict of interest The authors declare no conflict of interest.

\section{References}

1. McCullum C, Benbrook C, Knowles L, Roberts S, Schryver T (2003) Application of modern biotechnology to food and agriculture: food systems perspective. J Nutr Educ Behav 35:319-332

2. Rabinovich SV (1998) Importance of wheat-rye translocations for breeding modern cultivar of Triticum aestivum L. Euphytica 100:323-340

3. Fridman E, Carrari F, Liu YS, Fernie AR, Zamir D (2004) Zooming in on a quantitative trait for tomato yield using interspecific introgressions. Science 305:1786-1789

4. Neeraja CN, Vemireddy LR, Malathi S, Siddiq EA (2009) Identification of alternate dwarfing gene sources to widely used Dee-Gee-Woo-Gen (sd1) gene by molecular and biochemical assays in rice (Oryza sativa L.). Electron J Biotechnol 12:1-7

5. Jauhar A, Santiaguel FA (2011) Greener rice. Rice Today 10:27-29

6. Choudhary G, Ranjitkumar N, Surapaneni M, Deborah DA, Vipparla A, Anuradha G, Siddiq EA, Vemireddy LR (2013) Molecular genetic diversity of major Indian rice cultivars over decadal periods. PLoS ONE 8:e66197

7. van de Wouw M, van Hintum T, Kik C, van Treuren R, Visser B (2010) Genetic diversity trends in twentieth century crop cultivars: a meta analysis. Theor Appl Genet 120:1241-1252

8. Tanurdzic M, Vaughn MW, Jiang H, Lee TJ, Slotkin RK, Sosinski B, Thompson WF, Doerge RW, Martienssen RA (2008) Epigenomic consequences of immortalized plant cell suspension culture. PLoS Biol 6:e302

9. Lee LS (1988) Citrus polyploidy-origins and potential for cultivar improvement. Aust J Agric Res 39:735-747

10. Kijima Y, Sserunkuuma D, Otsuka K (2006) How revolutionary is the "Nerica Revolution"? Evidence from Uganda. Dev Econ 44:252-267

11. Ejeta G (2007) Breeding for Striga resistance in sorghum: exploitation of an intricate host-parasite biology. Crop Sci 47:S216-S-227

12. Ashikari M, Sakakibara H, Lin S, Yamamoto T, Takashi T, Asuka N, Enrique RA, Qian Q, Hidemi K, Makoto M (2005) Cytokinin oxidase regulates rice grain production. Science 309:741-745

13. Spielman D, Kolady D, Ward P (2013) The prospects for hybrid rice in India. Food Secur 5:651-665

14. Siddiq EA, Vemireddy LR, Nagaraju J (2012) Basmati rices: genetics, breeding and trade. Agric Res 1:25 
15. Yashitola J, Sundaram RM, Biradar SK, Thirumurugan T, Vishnupriya MR, Rajeshwari R, Viraktamath BC, Sarma NP, Sonti RV (2004) A sequence specific PCR marker for distinguishing rice lines on the basis of wild abortive cytoplasm from their cognate maintainer lines. Crop Sci 44:920-924

16. Joseph M, Gopalakrishnan S, Sharma RK, Singh VP, Singh AK, Singh NK, Mohapatra T (2004) Combining bacterial blight resistance and basmati quality characteristics by phenotypic and molecular marker-assisted selection in rice. Mol Breed 13:377-387

17. Balaji SP, Srikanth B, Hemanth KV, Subhakararao I, Vemireddy LR, Dharika N, Sundaram RM, Ramesha MS, Sambasivarao KRS, Viraktamath BC, Neeraja CN (2012) Fine mapping of Rf3 and Rf4 fertility restorer loci of WA-CMS of rice (Oryza sativa L.) and validation of the developed marker system for identification of restorer lines. Euphytica 187:421-435

18. Hui F, Yang N, Zhiyong L, Hao W (2011) A genetic male sterile line developed by molecular marker-assisted selection in Chinese cabbage (Brassica rapa ssp. pekinensis). Afr J Biotechnol 10:17706-17711

19. Mariani C, DeBeuckeleer MD, Truettner J, Leemans J, Goldberg RB (1990) Induction of male sterility in plants by a chimaeric ribonuclease gene. Nature 347:737-741

20. Gatehouse J (2013) Genetic engineering of crops crop/cropping for insect resistance crop/cropping for insect resistance. In: Christou P, Savin R, Costa-Pierce B, Misztal I, Whitelaw CB (eds) Sustainable food production. Springer, New York, pp 808-845

21. Liu X, Yang Z, Gao G, Lin Y, Zhu X, Yu J, He Y (2010) Development of Bt rice by molecular marker-assisted selection and assays for insect-resistance. Mol Plant Breed 1:1-5

22. Pal KK, Gardener BM (2006) Biological control of plant pathogens. The Plant Health Instructor. doi:10.1094/PHI-A2006-1117-02

23. Eilenberg J, Hajek A, Lomer C (2001) Suggestions for unifying the terminology in biological control. Biocontrol 46:387-400

24. Moslim R, Wahid MB, Kamarudin N, Ahmad SR, Hamid NH (2006) Research into the commercialization of Metarhizium anisopliae (Hyphomycetes) for biocontrol of the rhinoceros beetle, Oryctes rhinoceros (Scarabaeidae) in oil palm. J Oil Palm Res 18:37-49

25. Bhatnagar RK, Sree KS, Sachdev B (2011) Going full circle. Biotech News 6:140-142

26. Suh J-P, Jeung J-U, Noh T-H, Cho Y-C, Park S-H, Shin MS, Kim CK, Jena KK (2013) Development of breeding lines with three pyramided resistance genes that confer broad-spectrum bacterial blight resistance and their molecular analysis in rice. Rice 6:1-11

27. Wally O, Punja ZK (2010) Genetic engineering for increasing fungal and bacterial disease resistance in crop plants. GM Crops 1:199-206

28. Abel P, Nelson R, De B, Hoffmann N, Rogers S, Fraley RT, Beachy RN (1986) Delay of disease development in transgenic plants that express the tobacco mosaic virus coat protein gene. Science 232:738-743

29. Beachy RN (1997) Mechanisms and applications of pathogenderived resistance in transgenic plants. Curr Opin Biotechnol 8:215-220

30. Gonsalves D (1998) Control of papaya ringspot virus in papaya: a case study. Annu Rev Phytopathol 36:415-437

31. Bonfim K, Faria JC, Nogueira EOPL, Mendes ÉA, Aragão FJL (2007) RNAi-mediated resistance to bean golden mosaic virus in Genetically engineered common bean (Phaseolus vulgaris). Mol Plant Microbe Interact 20:717-726

32. Aragao FJL, Faria JC (2009) First transgenic geminivirusresistant plant in the field. Nat Biotech 27:1086-1088
33. Barclay A (2004) Feral play. Rice Today 3:15-19

34. Voller A, Bartlett A, Bidwell DE, Clark MF, Adamso AN (1976) The detection of viruses by enzyme-linked immunosorbent assay (ELISA). J Gen Virol 33:165-167

35. Siddiqui MZ (2010) Monoclonal antibodies as diagnostics; an appraisal. Indian J Pharm Sci 72:12-17

36. Henson JM (1993) The polymerase chain reaction and plant disease diagnosis. Annu Rev Phytopathol 31:81-109

37. Beringer JE (2003) Methods for risk assessment of transgenic plants. In: Ammann K, Jacot Yolande, Braun Richard (eds) Horizontal gene flow, 3rd edn. Springer, New York

38. Worthington M, Reberg-Horton C (2013) Breeding cereal crops for enhanced weed suppression: optimizing allelopathy and competitive ability. J Chem Ecol 39:213-231

39. Weih M, Didon U, Ronnbergwastljung A, Bjorkman C (2008) Integrated agricultural research and crop breeding: allelopathic weed control in cereals and long-term productivity in perennial biomass crops. Agric Syst 97:99-107

40. Basu C, Halfhill MD, Mueller TC, Stewart CN Jr (2004) Weed genomics: new tools to understand weed biology. Trends Plant Sci 9:391-398

41. Charles D (2001) Seeds of discontent. Science 294:772-775

42. Richards RA (2006) Physiological traits used in the breeding of new cultivars for water-scarce environments. Agric Water Manag 80:197-211

43. Steele KA, Price AH, Shashidhar HE, Witcombe JR (2006) Marker-assisted selection to introgress rice QTLs controlling root traits into an Indian upland rice variety. Theor Appl Genet 112:208-221

44. Bailey-Serres J, Fukao T, Ronald P, Ismail A, Heuer S, MacKill D (2010) Submergence tolerant rice: SUB1's journey from landrace to modern cultivar. Rice 3:138-147

45. James C (2008) Global status of commercialized biotech/GM crops. ISAAA Brief 39

46. Deikman J, Petracek M, Heard JE (2012) Drought tolerance through biotechnology: improving translation from the laboratory to farmers' fields. Curr Opin Biotechnol 23:243-250

47. Parida AK, Jha B (2010) Salt tolerance mechanisms in mangroves: a review. Trees Struct Funct 24:199-217

48. Saxena M, Roy SDR, Singla-Pareek SL, Sudhirkumar S, Sarin NB (2011) Overexpression of the glyoxalase II gene leads toenhanced salinity tolerance in Brassica juncea. Open Plant Sci J 5:23-28

49. Tuteja N (2010) A method to confer salinity stress tolerance to plants by helicase overexpression. In: Abdelhaleem MM (ed) Helicases. Humana Press, New York, pp 377-387

50. Sunkar R, Zhou X, Zheng Y, Zhang W, Zhu J-K (2008) Identification of novel and candidate miRNAs in rice by high throughput sequencing. BMC Plant Biol 8:1-17

51. Dodd IC, Ruiz-Lozano JM (2012) Microbial enhancement of crop resource use efficiency. Curr Opin Biotechnol 23:236-242

52. Yang J, Kloepper JW, Ryu C-M (2009) Rhizosphere bacteria help plants tolerate abiotic stress. Trends Plant Sci 14:1-4

53. Boonkerd N (2002) Development, of inoculant production and utilisation in Thailand. In: Inoculants and nitrogen fixation of legumes in Vietnam: proceedings workshop held in Hanoi, Vietnam, February 17-18, 2001, pp 95-104

54. Odame H (2002) Smallholder access to biotechnology: case of Rhizobium inocula in Kenya. Econ Polit Wkly 37:2748-2755

55. Peralta H, Mora Y, Salazar E, Encarnación S, Palacios R, Mora J (2004) Engineering the nifH promoter region and abolishing poly-beta-hydroxyl butyrate accumulation in Rhizobium etli enhance nitrogen fixation in symbiosis with phaseolus vulgaris. Appl Environ Microbiol 70:3272-3281

56. Rola AC, Chupungco AR (1996) Socio-economic evaluation and policy analysis of the commercialization of the rapid composting technology-phase II. Philippine Council for 
Agriculture, Forestry and Natural Resources Research and Development, College, Laguna, Philippines. (Unpublished mimeograph)

57. Adesemoye AO, Torbert HA, Kloepper JW (2009) Plant growth-promoting rhizobacteria allow reduced application rates of chemical fertilizers. Microb Ecol 58:921-929

58. Gianinazzi S, Gollate A, Binet M-N, van Tuinen D, Redecker D, Wipf D (2010) Agroecology: the key role of arbuscular mycorrhizas in ecosystem services. Mycorrhiza 20:519-530

59. Cakmak I, Graham RD, Welch RM (2004) Agricultural and molecular genetic approaches, to improving nutrition and preventing micronutrient malnutrition globally. In: Welch CRM (ed) Impacts of agriculture on human health and nutrition. Encyclopedia of Life Support Systems, Oxford

60. Ye X, Al-Babili S, Klöti A, Zhang J, Lucca P, Peter B, Ingo P (2000) Engineering the provitamin A ( $\beta$-carotene) biosynthetic pathway into (carotenoid-free) rice endosperm. Science 287: 303-305

61. Paine JA, Shipton CA, Chaggar S, Howells RM, Kennedy MJ, Gareth V, Susan WY, Edward H, Jessica LA, Aron LS, Rachel D (2005) Improving the nutritional value of golden rice through increased pro-vitamin A content. Nat Biotechnol 23:482-487

62. Harjes CE, Rocheford TR, Bai L, Brutnell TP, Kandianis CB, Sowinski SG, Stapleton AE, Vallabhaneni R, Williams M, Wurtzel ET, Yan J, Buckler ES (2008) Natural genetic variation in lycopene epsilon cyclase tapped for maize biofortification. Science 319:330-333

63. Yan J, Kandianis CB, Harjes CE, Bai L, Kim E-H, Yang X, Skinner DJ, Fu Z, Mitchell S, Li Q, Fernandez MG, Zaharieva M, Babu R, Fu Y, Palacios N, Li J, DellaPenna D, Brutnell T, Buckler ES, Warburton ML, Rocheford T (2010) Rare genetic variation at Zea mays crtRB1 increases [beta]-carotene in maize grain. Nat Genet 42:322-327

64. Babu R, Rojas N, Gao S, Yan J, Pixley K (2013) Validation of the effects of molecular marker polymorphisms in LcyE and CrtRB1 on provitamin A concentrations for 26 tropical maize populations. Theor Appl Genet 126:389-399

65. Chakraborty S, Chakraborty N, Agrawal L, Ghosh S, Narula K, Shekhar S, Naik PS, Pande PC, Chakrborti SK, Datta A (2010) Next-generation protein-rich potato expressing the seed protein gene Am A1 is a result of proteome rebalancing in transgenic tuber. Proc Natl Acad Sci 107:17533-17538

66. Meli VS, Ghosh S, Prabha TN, Chakraborty N, Chakraborty S, Datta A (2010) Enhancement of fruit shelf life by suppressing $\mathrm{N}$-glycan processing enzymes. Proc Natl Acad Sci. doi:10.1073/ pnas.0909329107

67. Paul S, Ali N, Gayen D, Datta SK, Datta K (2012) Molecular breeding of Osfer2 gene to increase iron nutrition in rice grain. GM Crop Food 3:310-316

68. Curtiss RI, Cardineau CA (1990) Oral immunisation by transgenic plants. World Patent Application WO 90/02484

69. Arakawa T, Yu J, Chong DKX, Hough J, Engen PC, Langridge WHR (1998) A plant-based cholera toxin B subunit-insulin fusion protein protects against the development of autoimmune diabetes. Nat Biotechnol 16:934-938

70. Kapusta J, Modelska A, Figlerowicz M, Pniewski T, Letellier M, Lisowa O, Yusibov V, Koprowski H, Plucienniczak A, Legocki AB (1999) A plant-derived edible vaccine against hepatitis B virus. FASEB J 13:1796-1799

71. McGarvey PB, Hammond J, Dienelt MM, Hooper DC, Fu ZF, Dietzschold B, Koprowski H, Michaels FH (1995) Expression of the rabies virus glycoprotein in transgenic tomatoes. Biotechnology 13:1484-1487

72. John I, Drake R, Farrell A, Cooper W, Lee P, Horton P, Grierson D (1995) Delayed leaf senescence in ethylene-deficient
ACC-oxidase antisense tomato plants: molecular and physiological analysis. Plant J 7:483-490

73. Vemireddy LR, Archak S, Nagaraju J (2007) Capillary electrophoresis is essential for microsatellite marker based detection and quantification of adulteration of Basmati rice (Oryza sativa). J Agric Food Chem 55:8112-8117

74. Moghaieb REA (2010) Transgenic rice plants expressing crylla5 gene are resistant to stem borer (Chilo agamemnon). GM Crops 1:288-293

75. Ramesh S, Nagadhara D, Pasalu IC, Kumari AP, Sarma NP, Reddy VD, Rao KV (2004) Development of stem borer resistant transgenic parental lines involved in the production of hybrid rice. J Biotechnol 111:131-141

76. Krishna G, Reddy PS, Ramteke P, Rambabu P, Tawar K, Bhattacharya P (2011) Agrobacterium-mediated genetic transformation of pigeon pea [Cajanus cajan (L.) Millsp.] for resistance to legume pod borer Helicoverpa armigera. J Crop Sci Biotechnol 14:197-204

77. Mehrotra M, Singh A, Sanyal I, Altosaar I, Amla DV (2011) Pyramiding of modified cry $1 A b$ and cry1Ac genes of Bacillus thuringiensis in transgenic chickpea (Cicer arietinum L.) for improved resistance to pod borer insect Helicoverpa armigera. Euphytica 182:87-102

78. Kanrar S, Venkateswari J, Kirti P, Chopra V (2002) Transgenic Indian mustard (Brassica juncea) with resistance to the mustard aphid (Lipaphis erysimi Kalt.). Plant Cell Rep 20:976-981

79. Hossain MA, Maiti MK, Basu A, Sen S, Ghosh AK, Sen S (2006) Transgenic expression of onion leaf lectin gene in Indian mustard offers protection against aphid colonization. Crop Sci 46:2022-2032

80. Mandaokar AD, Goyal RK, Shukla A, Bisaria S, Bhalla R, Reddy VS, Chaurasia A, Sharma RP, Altosaar I, Anandakumar $\mathrm{P}$ (2000) Transgenic tomato plants resistant to fruit borer ( $\mathrm{He}$ licoverpa armigera Hubner). Crop Prot 19:307-312

81. Saker MM, Salama HS, Salama M, El-Banna A, Abdel Ghany NM (2011) Production of transgenic tomato plants expressing Cry $2 \mathrm{Ab}$ gene for the control of some lepidopterous insects endemic in Egypt. J Genet Eng Biotechnol 9:149-155

82. Rai NP, Rai GK, Kumar S, Kumari N, Singh M (2013) Shoot and fruit borer resistant transgenic eggplant (Solanum melongena L.) expressing crylAa3 gene: development and bioassay. Crop Prot 53:37-45

83. Tabashnik BE, Dennehy TJ, Sims MA, Larkin K, Head GP, Moar WJ, Carrière Y (2002) Control of resistant pink bollworm (Pectinophora gossypiella) by transgenic cotton that produces Bacillus thuringiensis toxin Cry2Ab. Appl Environ Microbiol 68:3790-3794

84. Lin W, Anuratha CS, Datta K, Potrykus I, Muthukrishnan S, Datta SK (1995) Genetic engineering of rice for resistance to sheath blight. Nat Biotechnol 13:686-691

85. Shah J, Raghupathy V, Veluthambi K (2009) Enhanced sheath blight resistance in transgenic rice expressing an endochitinase gene from Trichoderma virens. Biotechnol Lett 31:239-244

86. Shah JM, Singh R, Veluthambi K (2013) Transgenic rice lines constitutively co-expressing tlp-D34 and chi11 display enhancement of sheath blight resistance. Biol Plant 57:351-358

87. Mondal K, Bhattacharya RC, Koundal KR, Chatterjee SC (2007) Transgenic Indian mustard (Brassica juncea) expressing tomato glucanase leads to arrested growth of Alternaria brassicae. Plant Cell Rep 26:247-252

88. Mehta R, Radhakrishnan T, Kumar A, Yadav R, Dobaria J, Thirumalaisamy PP, Jain RK, Chigurupati P (2013) Coat protein-mediated transgenic resistance of peanut (Arachis hypogaea L.) to peanut stem necrosis disease through Agrobacteriummediated genetic transformation. Indian J Virol 24:205-213 
89. Hayes PM, Corey AE, Mundt C, Toojinda T, Vivar H (2003) Registration of 'Tango' Barley Oregon Agricultural Exp. Stn. Manuscript No. 11893. Registration by CSSA. Crop Sci 43:729a-731-a

90. Eglinton J, Coventry S, Chalmers K (2006) Breeding outcomes from molecular Genetics. In: Mercer CF (eds) Breeding for success: diversity in action. Christchurch, New Zealand: proceedings of the 13th Australasian plant breeding conference, pp 743-749

91. Kosova K, Chrpova J, Sip V (2008) Recent advances in breeding of cereals for resistance to barley yellow dwarf virus-a review. Czech J Genet Plant Breed 44:1-10

92. Miklas PN, Grafton KF, Hauf D, Kelly JD (2006) Registration of partial white mold resistant pinto bean germplasm line USPTWM-1. Crop Sci 46:2339

93. Mutlu N, Miklas PN, Steadman JR, Vidaver AK, Lindgren DT, Reiser J, Coyne DP, Pastor-Corrales MA (2005) Registration of common bacterial blight resistant pinto bean germplasm line ABCP-8 A contribution of the University of Nebraska, Agricultural Research Division, Lincoln, NE 68583. Journal Series no. 14628. Registration by CSSA. Crop Sci 45:806-807

94. Mutlu N, Urrea CA, Miklas PN, Steadman JR, Pastor Corrales MA, Lindgren DT, Reiser J, Vidaver AK, Coyne DP (2008) Registration of common bacterial blight, rust and bean common mosaic resistant great northern bean germplasm line ABC-weighing. J Plant Regist 2:120-124

95. Miklas PN, Smith JR, Singh SP (2006) Registration of common bacterial blight resistant dark red kidney bean germplasm line USDK-CBB-15. Registration by CSSA. Crop Sci 46:1005-1007

96. Babu R, Nair SK, Prasanna BM, Gupta HS (2004) Integrating marker-assisted selection in crop breeding-prospects and challenges. Curr Sci 87:607-619

97. Dar WD, Reddy BVS, Gowda CLL, Ramesh S (2006) Genetic resources enhancement of ICRISAT-mandate crops. Curr Sci 91:880-884

98. Dwivedi SL, Crouch JH, Mackill DJ, Xu Y, Blair MW, Ragot M, Upadhyaya HD, Ortiz R (2007) The molecularization of public sector crop breeding: progress, problems, and prospects. Adv Agro 95:163-318

99. Cheng S-H, Zhuang J-Y, Fan Y-Y, Du J-H, Cao L-Y (2007) Progress in research and development on hybrid rice: a superdomesticate in China. Ann Bot 100:959-966

100. Toenniessen GH, O'Toole JC, DeVries J (2003) Advances in plant biotechnology and its adoption in developing countries. Curr Opin Plant Biol 6:191-198
101. Carlos DMJ (2007) Philippines Scientists develop flood-tolerant biotech rice. Business Mirror. 19-September ed. http://www.bic. searca.org/news/2007/sep/phi/19.html

102. Kole C (2011) Wild crop relatives: genomic and breeding resources. In: Kole C (ed) Legume crops and forages, vol 25 Springer, p 321

103. Chandrashekar MV (2007) UAS develops aerobic rice. Food and Beverage New. www.fnbnews.com/article/detarchive.asp?arti cleid $=22118 \&$ sectionid $=34$

104. Gopalakrishnan S, Sharma RK, Anand Rajkumar K, Joseph M, Singh VP, Singh AK, Bhat KV, Singh NK, Mohapatra T (2008) Integrating marker assisted background analysis with foreground selection for identification of superior bacterial blight resistant recombinants in Basmati rice. Plant Breed 127:131-139

105. Sundaram R, Vishnupriya M, Biradar S, Laha G, Reddy G, Rani NS, Sarma NP, Sonti RV (2008) Marker assisted introgression of bacterial blight resistance in Samba Mahsuri, an elite indica rice variety. Euphytica 160:411-422

106. Neeraja CN, Maghirang-Rodriguez R, Pamplona A, Heuer S, Collard BCY, Septiningsih EM, Vergara G, Sanchez D, Xu K, Ismail AM, Mackill DJ (2007) A marker-assisted backcross approach for developing submergence-tolerant rice cultivars. Theor Appl Genet 115:767-776

107. Steele K (2009) Novel upland rice variety bred using markerassisted selection and client-oriented breeding released in Jharkhand. India. Plant Breed News 200:2009

108. Core J (2005) New soybean resists nematodes and pathogens. ARS News Service. www.ars.usda.gov/IS/pr/2005/050929.2. htm. Accessed 20 March 2009

109. Lippman ZB, Semel Y, Zamir D (2007) An integrated view of quantitative trait variation using tomato interspecific introgression lines. Curr Opin Genet Dev 17:545-552

110. Hospital F (2009) Challenges for effective marker-assisted selection in plants. Genetica 136:303-310

111. Wheat CAP (2009) Germplasm release. University of California, Davis. http://maswheat.ucdavis.edu/Achievements/culti vars2007.htm

112. Kidwell K, Santra D, deMacon V, Shelton G, Santra M, Burke A, Nyongesa W, Carter A (2008) Precision breeding, wheat research progress report, Washington State University, Agricultural Research Center. http://arc.wsu.edu/Links/images/2008/ 3572Kidwell.pdf

113. A National Small Grains Variety Review Board (2007) www. aosca.org/VarietyReviewBoards/2007\%20SGNVRB\%20Report_ Final_042607.pdf 